\title{
Seosed õppejõu õpetamisviisi ja üliõpilase õppimist toetavate ning takistavate tegurite vahel õppeaines
}

\author{
Kaire Uiboleht ${ }^{\text {al }}$, Mari Karm ${ }^{\text {a, b }}$ \\ ${ }^{a}$ Tartu Ülikooli personaliarenduskeskus \\ ${ }^{b}$ Tartu Ülikooli haridusteaduste instituut
}

\begin{abstract}
Annotatsioon
Kõrghariduses võib õppeaine õpikeskkonda kirjeldada õppejõu õpetamisviisi kaudu. Varasemad uurimused on kirjeldanud sisu- ja õppimiskeskset õpetamisviisi ning nende põimumist. Uurimused, mis on keskendunud üliõpilaste kirjeldatud õppimist toetavate ja takistavate õpikeskkonna elementidele, ei selgita, kuidas need on seotud õppejõu sisu- või õppimiskeskse õpetamisviisiga konkreetse õppeaine kontekstis. Samas on õppeaine arendamise seisukohast oluline seda seost mõista. Selle artikli eesmärk on tuua välja seoseid õppejõudude kirjeldatud õpetamisviisi ning üliõpilaste kirjeldatud õppimist toetavate ja takistavate õpikeskkonna elementide vahel just õppeaine tasandil. Artikkel tugineb mitme õppeaine uuringule, kus intervjueeriti kolme õppeaine õppejõudu ja üliõpilasi. Andmete kvalitatiivsest analüüsist selgub, et üliõpilased ei taju õpetamisviiside põimumist alati õppimist takistavana. Pigem takistavad üliõpilaste õppimist õppejõu ebaselged ootused ja üldsõnalised juhendid.
\end{abstract}

Võtmesõnad: õpikeskkond, õppejõu õpetamisviis, õppimist toetavad õpikeskkonna elemendid, õppimist takistavad õpikeskkonna elemendid

\section{Sissejuhatus}

Kõrgkoolis õppimise kvaliteeti mõjutavad mitmed tegurid ning seetõttu on teadvustatud, et tegu on keerulise nähtusega. Õppeaine tasandil mõistetakse õppimist järjest enam konstruktivistliku õpikäsituse kontekstis (Biggs \& Tang, 2008). Selle järgi on õppimine-õpetamine koostöine protsess, kus õppejõu peamiseks ülesandeks on kujundada õpikeskkond, mis pakub üliõpilastele tulemuslikke ja tähendusrikkaid õppimistegevusi (Barnett \& GuzmánValenzuela, 2017). Õppijate roll on olla aktiivne ja haaratud ning arendada uusi teadmisi, oskusi ja üldpädevusi (Tynjälä, 1999).

Personaliarenduskeskus, personaliosakond, Tartu Ülikool, Lossi 36, 51003 Tartu; kaire.uiboleht@ut.ee. 
Õpikeskkonna ja üliõpilaste õppimise seostele keskendunud uurimuste tulemused ei kinnita üksmeelselt, et näiteks konstruktivistlikust õpikäsitusest lähtuvad õpikeskkonnad oleks alati seotud sügava õppimisega (Baeten, Kyndt, Struyven, \& Dochy, 2010; Gijbels, Segers, \& Struyf, 2008). Samas kui õpikeskkonda on kirjeldatud õppejõu õpetamisviisi kaudu, on leitud, et õppija- või õppimiskeskne õpetamisviis (student- or learning-focused approach to teaching) on seotud sügava õppimisega ning õppejõu- või sisukeskne õpetamisviis (teacher- or content-focused approaches to teaching) on pigem seotud pindmise õppimisega (Prosser \& Trigwell, 2014).

Kuna õppejõudude loodud õpikeskkonna ja üliõpilaste õppimise seostele keskendunud uurimuste tulemused ei ole alati olnud ootuspärased (nt Gijbels et al., 2006; Struyven, Dochy, Janssens, \& Gielen, 2006), on edasiste uurimuste põhjal püütud mõista, mil viisil mõjutab õppimise kvaliteeti see, kuidas õppijad tajuvad õppejõu loodud õpikeskkonda (Baeten et al., 2010; Segers, Martens, \& Van den Bossche, 2008). Nimetatud uuringutes kirjeldatakse üldiselt tegureid, mis üliõpilaste arvates toetavad või takistavad nende õppimist, kuid nende seost konkreetses aines õppejõu loodud õpikeskkonnaga või õppejõu õpetamisviisiga ei ole selgitatud (nt Hailikari, Tuononen, \& Parpala, 2018; Ruohoniemi \& Lindblom-Ylänne, 2009). Samas on õppeaine arendamise seisukohast oluline mõista, kuidas on seotud õppejõu õpetamisviis ning üliõpilaste õppimist toetavad ja takistavad tegurid.

\section{Teoreetiline ülevaade}

\section{Õppeaine õpikeskkonna kirjeldamine õppejõudude õpetamisviisi kaudu}

Õpikeskkonnas arendab õppejõud mitmeid õpikeskkonna elemente: kirjeldab õppimise tulemuse ehk õpiväljundid, valib õpetamise ja hindamise meetodid ja ülesanded ning juhendab õppijate tegevusi (Entwistle, McCune, \& Hounsell, 2002). Õppeaine õpikeskkonda saab kirjeldada õppejõudude õpetamisviisi kaudu (approaches to teaching), kuna see lähenemine toob esile õpetamise eri elemente (Barnett \& Guzmán-Valenzuela, 2017). Õpetamisviisi analüüsivates uurimustes eristatakse õpetamise kavatsusi (teaching intention) ja õpetamistegevusi, mida õppejõud tavaliselt rakendab (teaching strategy) (Postareff \& Lindblom-Ylänne, 2008). Võttes kokku peamised selle valdkonna uuringud (Samuelowicz \& Bain, 1992; Trigwell, Prosser, \& Taylor, 1994; Van Driel, Verloop, Van Werven, \& Dekkers, 1997; Kember ja Kwan, 2000; Postareff \& Lindblom-Ylänne, 2008), võib öelda, et eristatakse kahte vastandlikku õpetamisviisi: õppejõu- või sisukesksed ja üliõpilas- või õppimiskesksed. 
Õppejõu- või sisukeskse õpetamisviisi korral on õpetamise peamine kavatsus õppeaine sisu ja teadmiste edasiandmine (Postareff \& Lindblom-Ylänne, 2008). Sisu esitamiseks kasutatakse loengu meetodit, näidete toomist ja õppejõu kogemuste jagamist. Üliõpilastes nähakse info vastuvõtjaid. Hindamisel on peamine kavatsus óppijate väline motiveerimine ja kontrollimine (kas on ikka õpitud) ning seetõttu rakendab õppejõud sageli traditsioonilisi teste ja kontrolltöid. Sisukeskse õpetamisviisi korral varieerib õppejõud õpetamise ja hindamise meetodeid vähesel määral.

Üliõpilas- või õppimiskeskse õpetamisviisi puhul on õpetamise eesmärk õppija sügavate teadmiste omandamine, arusaama muutmine ja üldpädevuste arendamine (Postareff \& Lindblom-Ylänne, 2008). Õppimise kavandamisel püüab õppejõud arvesse võtta õppijate varasemaid teadmisi ja kogemusi. Uurijad (Kember ja Kwan, 2000; Postareff \& Lindblom-Ylänne, 2008) on kirjeldanud, et üliõpilas- või õppimiskeskse õpetamisviisi korral rakendatakse õppemeetodeid, mis võimaldavad õppijal olla õppeprotsessis haaratud (nt arutleda õpitava üle, saada tagasisidet ja kasutada seda õppimise käigus). Seega kirjeldatakse óppijaid kui aktiivseid teadmiste ja arusaamade loojaid. Hindamise peamine eesmärk on sügava õppimise toetamine ning seetõttu on õpetamise ja hindamise protsess sageli põimunud. Üliõpilas- või õppimiskeskse õpetamisviisi korral rakendab õppejõud nii õpetamisel kui ka hindamisel erinevat tüüpi ülesandeid ja meetodeid.

Uurijad (Postareff, Katajavouri, Lindblom-Ylänne, \& Trigwell, 2008; Stes \& Van Petegem, 2014) on leidnud, et õppejõudude õpetamisviiside kirjeldustes ei esine sisu- ja õppimiskeskse õpetamisviisis elemendid rangelt lahus, vaid võivad põimuda. Näiteks kuigi õppejõu kavatsus on toetada õppijate sügavat õppimist ja arusaamist, võib ta õpetamistegevusena siiski rakendada peamiselt loengut, kus õppijatel on vähe võimalusi õpitava üle arutleda. Õpetamisviiside põimumine on nähtus, mida on avatud üksikutes uuringutes (Postareff $e t$ al., 2008; Stes \& Van Petegem, 2014) ning selle mõju õppimisele on vähe uuritud. Kuigi mõned uuringud on leidnud, et õpetamisviiside põimumine on seotud üliópilaste pindmise õppimisega (Prosser et al., 2003; Uiboleht, Karm, \& Postareff, 2018), ei too need välja, mis nendes õpikeskkondades toetab või takistab üliõpilaste õppimist.

\section{Üliõpilaste kirjeldatud õppimist toetavad ja takistavad tegurid}

Varasemates õppejõudude õpetamisviisi ja üliõpilaste õppimise sügavuse seoste selgitamisele keskendunud uuringutes on leitud, et õppimise sügavust mõjutab see, kuidas üliõpilased tajuvad õpikeskkonda (Baeten et al., 2010; Entwistle, 2007). Viimane omakorda kujuneb üliõpilase personaalsete tegurite (nt isiklik 
huvi) ja õppejõu kujundatud õpikeskkonna koostoime tulemusena (Entwistle, 2007). Seetõttu võivad sama õppeaine üliõpilased tõlgendada õpikeskkonda erinevalt ning samas õpikeskkonnas ka erinevalt õppida (Baeten et al., 2010).

Üliõpilaste kirjeldatud õppimist toetavateks õpikeskkonna teguriteks on uurimustes arvatud õppejõu loodud õpikeskkonna elemendid (nt õpiväljundid, õpetamise ja hindamise meetodid ning nende kooskõla), mida üliõpilased kirjeldavad õppimist toetavana või kui need on seotud sügava õppimisega (Hailikari et al., 2018; Parpala, Lindblom-Ylänne, Komulainen, Litmanen, \& Hirsto, 2010; Ruohoniemi \& Lindblom-Ylänne, 2009). Uuringute põhjal võib välja tuua, et üliõpilased kirjeldavad õppejõu loodud õpikeskkonda õppimist toetavana, kui õpetamine ja õpiväljundid on kooskõlas; õppimise eesmärgid ja õpiväljundid on mõistetavad ning kui üliõpilased teavad, mis neid õppeaines ees ootab ja millal on tööde tähtajad (Parpala et al., 2010; Parpala, Lindblom-Ylänne, \& Rytkönen, 2011; Hailikari \& Parpala, 2014). Lisaks on leitud, et üliõpilaste õppimist toetab võimalus õpitavat rakendada, selle üle arutleda kas õppejõu või teiste õppijatega; õppejõu vaimustumine ainest ja toetav hoiak õppijate suhtes. Kujundava hindamise juures toovad autorid välja, et üliõpilased kirjeldavad tagasisidet õppimist toetavana, kui tagasiside on asjakohane ja konstruktiivne ning võimaldab selle põhjal õpitavat edasi arendada (Esterhazy, Nerland, \& Damşa, 2019). Hindamise juures on rõhutatud, et õppimist toetavad elulised hindamisülesanded (Baeten et al., 2010).

Üliõpilaste kirjeldatud õppimist takistavateks teguriteks on uurimustes arvatud õppejõu kujundatud õpikeskkonna elemendid, mida üliõpilased ise kirjeldavad õppimist takistavana või kui need on seotud pindmise õppimisega (Hailikari et al., 2018; Ruohoniemi \& Lindblom-Ylänne, 2009). On leitud, et õppejõukeskne õpetamine on seotud üliõpilaste pindmise õppimisega (Prosser \& Trigwell, 2014). Üliõpilaste arvates takistab nende õppimist, kui on liiga vähe auditoorset õppetööd, vähe võimalusi õpitava üle arutleda (kas õppejõu või kaasõppijatega) ja vähe tagasisidet (Struyven et al., 2006; Hailikari et al., 2018). Samuti võib uurimuste põhjal väita, et kui õppimine on vähe juhendatud (nt vähe teavet ülesannete kohta), siis üliõpilased kalduvad õppima pindmiselt (Kyndt, Dochy, Struyven, \& Cascallar, 2011; Hailikari \& Parpala, 2014). Hindamise juures on täheldatud, et kokkuvõttev hindamine (hinnatakse ainult õppeprotsessi lõpus) ei toeta õppimist, isegi kui rakendatakse elulisi hindamisülesandeid (Mumm, Karm, \& Remmik, 2016). Üliõpilaste arvamuste põhjal ei toeta nende õppimist kumbki äärmus: ei liiga suur ega liiga väike töökoormus; ei liiga keerulised ega liiga lihtsad ülesanded (Ruohoniemi \& LindblomYlänne, 2009).

Eelnevad uurimused nii õppejõu kirjeldatud õpetamisviisi kui ka üliõpilaste kirjeldatud õppimist toetavate ja takistavate õpikeskkonna tegurite seoste 
analüüsimisel on tehtud üldisel või õppekava tasandil, keskendumata konkreetse aine kontekstile. Õppeaine tasandi analüüs võimaldaks sügavamalt mõista õpetamisviisile omaste elementide ja nende koosmõju seoseid üliõpilaste tajutud õppimist toetavate ja takistavate õpikeskkonna tegurite vahel.

Siinse uuringu eesmärk on tuua välja seoseid õppejõudude kirjeldatud õpetamisviisi ning üliõpilaste kirjeldatud õppimist toetavate ja takistavate õpikeskkonna tegurite vahel õppeaine tasandil. Otsitakse vastuseid järgmistele uurimisküsimustele.

1) Kuidas õppejõud kirjeldavad õpetamisviisi (st õpetamiskavatsusi ja -tegevusi) õppeaine õpetamisel?

2) Milliseid õppejõu õpetamisviisiga seotud õpikeskkonna elemente kirjeldavad üliõpilased õppimist toetavate või takistavate teguritena?

\section{Metoodika}

\section{Valim}

Artikkel põhineb mitme juhtumi võrdleval uuringul, milles käsitleti juhtumina ühte õppeainet ning vaatluse all oli kolm bakalaureusetaseme õppeainet. Juhtumiuuring (Thomas, 2016) võimaldab nähtust vaadelda ja kirjeldada reaalelulises kontekstis eri osaliste perspektiividest. Kui ühe juhtumi uuring vaatleb nähtust (üliõpilaste kirjeldatud õppimist toetavad ja takistavad tegurid) ühes kontekstis (õppejõu õpetamisviis õppeaines), siis mitme juhtumi kaasamine uuringusse võimaldab konteksti ja nähtuse vahelisi seoseid juhtumite vahel võrrelda, lisades seeläbi uurimistöö tulemustele usaldusväärsust.

Juhtumite ehk õppeainete valikul oli üks olulisi kriteeriume, et nende sisu ja õpiväljundid oleks sarnased ning need oleksid samast valdkonnast (sotsiaalteadused). See kriteerium tulenes varasematest uurimustest, mis osutavad õppeaine valdkonna ja õpiväljundite arvestamise vajalikkusele uurimistöös (Baeten et al., 2010). Teine oluline kriteerium oli, et õppeinfosüsteemis toodud õpetamis- ja hindamisviisid oleksid õppeainetel erinevad.

Üliõpilaste kaasamisel intervjueeritavate valimisse peeti silmas, et valim oleks võimalikult heterogeenne, ning seetõttu kutsuti intervjuule erinevaid hindeid saanud üliõpilasi, sest uuringud viitavad, et üliõpilaste õpikogemus ja hinded võivad olla seotud (Alameida, Teixeira-Dias, Martinho, \& Balasooriya, 2011). Kokku saadeti kutse uurimuses osalemiseks neljale õppejõule ning 92 üliõpilasele. Uurimuses järgiti vabatahtlikkuse printsiipi ning seetõttu kujunes intervjueeritavate õppejõudude arvuks kolm ja üliõpilaste arvuks 33 (I juhtum 12, II juhtum 14 ja III juhtum 7 üliõpilast). 


\section{Andmekogumine}

Andmekogumise meetodina kasutati nii üliõpilaste kui ka õppejõudude puhul poolstruktureeritud intervjuusid, mille abil saab uurida tegevuste, käitumise kirjeldusi ja nende põhjendusi (Brinkman, 2014). Õppeaine vastutavaid õppejõude intervjueeriti kahel korral. Esimesel korral paluti õppejõul kirjeldada õpetamise eesmärke, ootusi üliópilastele, õppeaine ülesehitust, õpetamise ja hindamise meetodeid ning ülesandeid. Teisel korral esitati täpsustavaid küsimusi hindamise kohta. Igat üliõpilast intervjueeriti üks kord ning intervjuude peamine eesmärk oli uurida, kuidas üliõpilased kirjeldasid õppeaine õpikeskkonda; mida nad enda arvates aines oppisid; kuidas nad õppisid (milliseid õppimistegevusi tegid) ja millised olid tegevuste põhjendused. Õppejõudude intervjuud kestsid 120 kuni 160 minutit ning üliõpilaste omad 40 kuni 80 minutit. Andmed koguti aastatel 2012-2013 ning intervjuusid tegid mõlemad autorid. Kõik intervjuud transkribeeriti sõna-sõnalt.

\section{Andmeanaliüis}

Intervjuude analüüsimisel kasutati kvalitatiivset induktiivset sisuanalüüsi, mis võimaldab andmeid analüüsida süsteemselt, samas jääda koodide, alakategooriate ja kategooriate moodustamisel avatuks ning andmetest lähtuvaks (Schreier, 2012). Andmeanalüüs koosnes neljast etapist.

1) Tähendusüksuste valimine ja tihendamine. Tähendusüksuste valimisel lähtuti uurimisküsimustest, valides õppejõudude intervjuudest tähendusüksused, mis kirjeldasid õpetamisviisi, ning üliõpilaste intervjuudest tähendusüksused, mis kirjeldasid õppimist toetavaid ja takistavaid tegureid. Seejärel kanti valitud tähendusüksused MS Exceli tabelisse. Kõikide tähendusüksuste puhul kasutati järgneva kodeerimise hõlbustamiseks sisu tihendamist ehk kokkuvõtete tegemist.

2) Õppejõudude ja üliõpilaste intervjuudest valitud tähendusüksuste kodeerimine.

3) Koodide rühmitamine. Eelneva etapi tulemusena saadud koodid koondati alakategooriatesse ja kategooriatesse. Koodide rühmitamise põhimõtteks oli sarnasus: koodid pidid mingi tunnuse poolest sarnanema (nt koodid, mis kirjeldasid tagasisidet, paigutati ühe alakategooria alla).

4) Võrdlustabeli loomine. Õppejõudude ja üliõpilaste intervjuude tulemused koondati tabelisse, lähtudes nii õppejõudude kui ka üliõpilaste intervjuude analüüsimise tulemusena saadud alakategooriatest ja kategooriatest. 
Uurimistulemuste usaldusväärsuse tagamiseks arutasid autorid tähendusüksuste valikut, kodeerimist ja koodide rühmitamist. Tulemuste osas toodud intervjuukatkendid on parema mõistetavuse eesmärgil toimetatud, eemaldades täitesõnad ja kordused. Õppejõudude intervjuuväljavõtted on märgitud Õ-tähe ja numbriga, mis viitab juhtumile. Üliõpilaste intervjuuväljavõtted on märgitud Ü-tähe ja kahe numbriga, millest esimene näitab juhtumi numbrit ja teine üliõpilase intervjuu numbrit.

\section{Tulemused}

\section{Õppeainete õpetamise ja hindamise kontekst}

Selles alapeatükis esitatakse õppeainete õpikeskkonna kirjeldused, mis saadi õppejõudude intervjuude analüüsimise tulemusena. Kirjelduste tõlgendamisel on soovitud mõista, kuivõrd õppimis- või sisukeskne oli õppejõu õpetamise kavatsus ning õpetamistegevus konkreetses õpetamise elemendis (kavandamine, õpetamine, hindamine) (vt tabel 1).

Tabel 1. Õppeainete õpikeskkonna kirjeldus õppejõudude õpetamisviisi kaudu

\begin{tabular}{|c|c|c|c|}
\hline & I juhtum/õppeaine & II juhtum/õppeaine & III juhtum/õppeaine \\
\hline \multirow{2}{*}{ 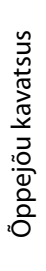 } & Õppimiskeskne: & Sisukeskne: & $\begin{array}{l}\text { Õppimis-ja sisukeskse } \\
\text { õpetamisviisi põimumine: }\end{array}$ \\
\hline & $\begin{array}{l}\text { Õppejõu eesmärk oli toetada } \\
\text { üliõpilaste õpiväljundite } \\
\text { saavutamist erinevate ja } \\
\text { pidevate õppimistegevuste } \\
\text { kaudu }\end{array}$ & $\begin{array}{l}\text { Õppejõu eesmärk oli } \\
\text { anda edasi aine sisu ning } \\
\text { tagada võimalikult paljude } \\
\text { üliõpilaste aine sooritamine }\end{array}$ & $\begin{array}{l}\text { Õppejõu eesmärk oli anda } \\
\text { edasi aine sisu ning pakkuda } \\
\text { üliõpilastele autentset } \\
\text { kogemust }\end{array}$ \\
\hline \multirow{5}{*}{ 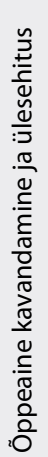 } & Õppimiskeskne: & $\begin{array}{l}\text { Õppimis-ja sisukeskse } \\
\text { õpetamisviisi põimumine: }\end{array}$ & Sisukeskne: \\
\hline & Loenguid 0 tundi & Loenguid 32 tundi & Loengud 20 tundi \\
\hline & Seminarid 30 tundi & Seminarid 14 tundi & Seminarid 14 tundi \\
\hline & $\begin{array}{l}\text { Teadmiste loomiseks kavandas } \\
\text { õppejõud üliõpilaste iseseisva } \\
\text { töö õpiku põhjal }\end{array}$ & $\begin{array}{l}\text { Loengud kavandas õppejõud } \\
\text { uue teabe edastamiseks. }\end{array}$ & $\begin{array}{l}\text { Loengud kavandas õppejõud } \\
\text { uue teabe edastamiseks. }\end{array}$ \\
\hline & $\begin{array}{l}\text { Seminarides kavandas } \\
\text { õppejõud teadmiste } \\
\text { rakendamise ja õpitava üle } \\
\text { arutlemise }\end{array}$ & $\begin{array}{l}\text { Seminarides kavandas } \\
\text { õppejõud teadmiste } \\
\text { rakendamise ja õpitava üle } \\
\text { arutlemise }\end{array}$ & $\begin{array}{l}\text { Seminarides kavandas } \\
\text { õppejõud üliõpilaste } \\
\text { rühmaprojektide } \\
\text { vahetulemuste esitlemise }\end{array}$ \\
\hline
\end{tabular}




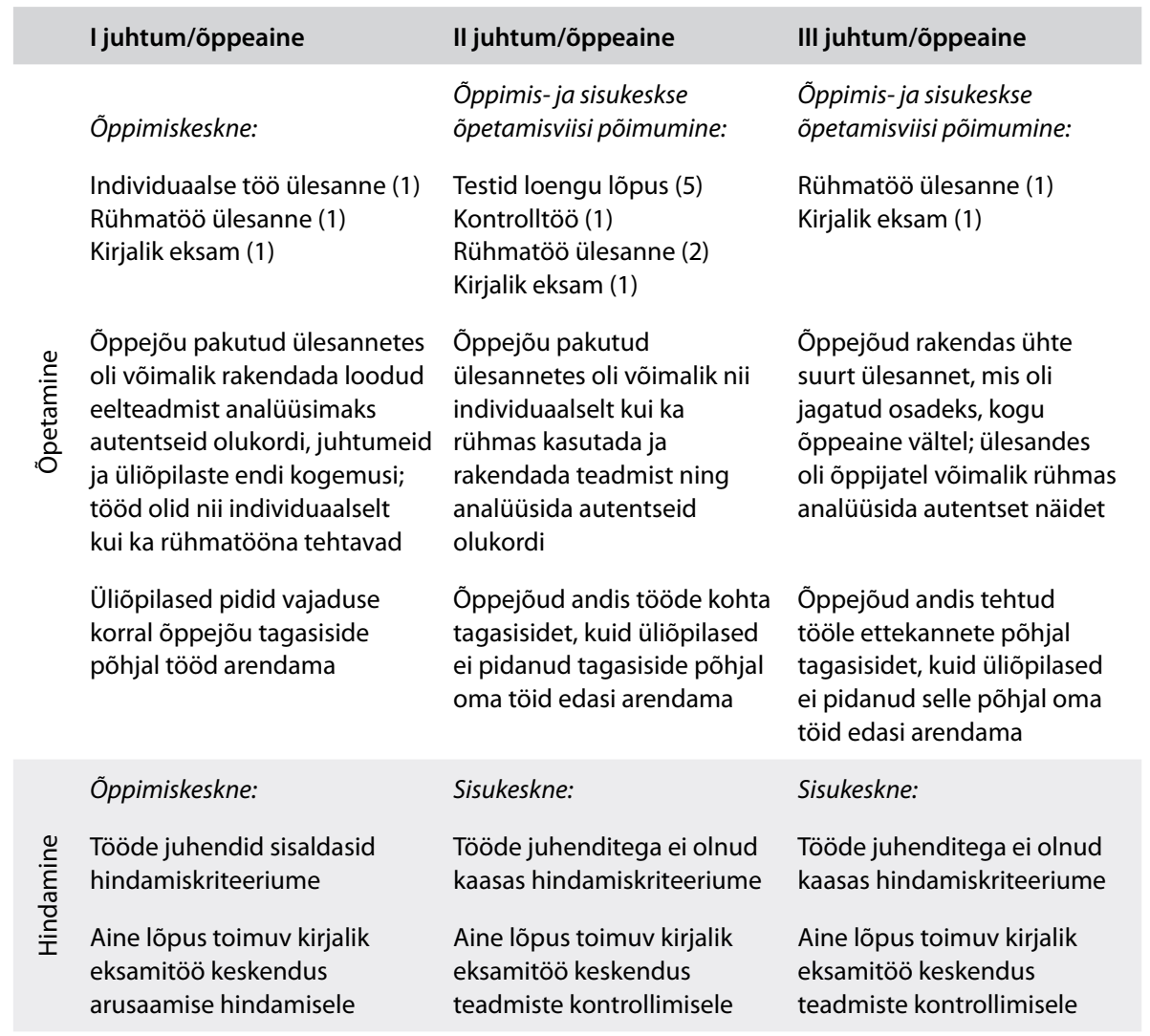

Õppejõududega tehtud intervjuude analüüsi tulemusena ilmnes, et esimese juhtumi õppejõu kirjeldatud õppeaine õpikeskkonna puhul olid ópetamise kavatsused ja õpetamistegevused kõikides elementides õppimiskesksed. Teise ja kolmanda juhtumi õppejõudude kirjeldustest selgus, et nende õppeaine õpikeskkonnas põimusid sisu- ja õpetamiskeskse õpetamisviisi elemendid nii õpetamise kavatsuste kui ka õpetamis- ja hindamistegevuste puhul.

\section{Seosed õppejõudude kirjeldatud õpetamisviisi ning üliõpilaste kirjeldatud óppimist toetavate ja takistavate õpikeskkonna tegurite vahel}

Selles peatükis on tulemused esitatud lähtuvalt kolmest kategooriast ja üheksast alakategooriast, milles avaldus seos õppejõu õpetamisviisi ja üliõpilaste kirjeldatud õppimist toetavate ja takistavate tegurite vahel. 


\section{Õppeaine kavandamine ja ülesehitus}

Õppeaine ülesehitus ja sidusus. Esimese juhtumi õppejõud kirjeldas õpetamise kavatsusena üliõpilaste õpiväljundite saavutamist ning seetõttu ta jälgis aine ülesehitamisel, et õppijad saaksid õpitava materjaliga tegeleda korduvalt ja eri perspektiividest ning aine jooksul tehtavad õppimis- ja hindamisülesandeid toetaksid õpiväljundite saavutamist. Lisaks selgitas esimese juhtumi õppejõud, et tema jaoks on oluline, et aine jooksul tehtavad ülesanded oleksid omavahel seotud, st üks ülesanne juhib teiseni.

Mul oligi see asi niimoodi disainitud, see kogu nende (üliópilaste) óppimine, et kui nad lugesid ópikust mingit asja, et siis nad hakkasid juba oma tööga tegelema ja juba sellesama ütleme teema raames (tuli järgmine ülesanne) ja niimoodi läks see kogu aeg nagu edasi. (Õ.1)

Sama juhtumi üliõpilaste intervjuudest ilmnes, et ka nende jaoks tundus õppeaine ülesehitus sidus ning see toetas nende õppimist. Üliõpilaste intervjuudes kajastus, et nad mõistsid, kuidas olid aine õpiväljundid, õppemeetodid ja hindamine omavahel kooskõlas.

Õpiväljundid olid välja toodud ... neid kõiki täideti ära kogu selle töö käigus. Sa saad väga selgelt aru, et mida õppejõud tahab näiteks sellega, kui sa teed [nimetab töö], mida óppejõud tahab sinu käest, kuidas ta palub sul teha [nimetab töö], et kuidas need asjad kokku lähevad. Sa ise näed ka neid seoseid, mis kuskil tekivad. (Ü.1.1)

Teise juhtumi õppejõud ei väljendanud intervjuus kooskõla õpiväljundite, ópetamise ja hindamise tegevuste või ülesannete vahel. Seevastu sama juhtumi üliõpilased tõid välja ebakõla õpetamise ja hindamise vahel, st õppeprotsessi käigus tehtavad ülesanded ja aine lópus toimuv eksam (hindamisülesanne) ei olnud nende arvates kooskõlas ning eeldasid erinevat õppimist. Näiteks õppeprotsessi käigus tehtavad ülesanded taotlesid arusaamist, ent eksam eeldas nende arvates vaid meeldejätmist. Samas, kuna üliõpilased said eksamiküsimuste tüübi teada alles eksamil, tähendas see, et nad õppisid eksamiks aine jooksul kujunenud ettekujutuse järgi, milline tuleb eksam. Intervjuudes üliõpilased küll väljendasid oma rahulolematust, et eksam oli oodatust teistsugune, kuid ei saanud seda arvesse võtta eksamiks valmistudes.

Tegelikult mulle meeldisid selles aines grupitööd, need olid sellised suhteliselt praktilised. Mulle nagu jäigi sellest ainest mulje - óppejõud ka rääkis seda -, et üks asi on teooria ja teine on see, kuidas sa nagu praktiliselt seda rakendada saad ja kas sa saad sellest üldse aru. Ja siis tuleb eksam, kus ... põhimõtteliselt 
oleks pidanud lihtsalt kõik skeemid pähe tuupima ja mitte nagu mõttega. See oli väike üllatus. ... Ma lootsin või ootasin, et ta [eksamitöö] on praktilisem või päriselust ka, et tood näiteid, et kuidas sa seda rakendaksid ... rohkem aruteluküsimusi. Aga selliseid ei olnud. (Ü.2.6)

Kolmanda juhtumi õppejõud nentis, et ta kavandas loengut ja praktikumi eraldi ega jõudnud kooskõla peale mõelda. Kordamisküsimused ja eksami sisu olid õppejõu arvates küll hästi kooskõlas, kuid kogu aine vältel tehtava ülesande sidusust loengutega ei jõudnud ta planeerida.

Loengumaterjalid valmistasin ette, praktikat visualiseerisin ... tegin kahte osa eraldi, tehniliselt. Aga mõelda, kuidas nad nagu koos on, ei jäänud aega ja ei olnud ka palju kogemusi [konkreetselt selle aine kontekstis] (Õ.3)

Sama juhtumi üliõpilased kirjeldasid ebakõla teadmiste omandamise protsessi ja ülesande vahel, selgitades, et kuna neil ei olnud piisavalt teadmisi ülesande tegemiseks, siis nad õppisid pindmiselt.

Rühmatöö [ülesanne] ja see, kuidas koolis asjad käisid ei olnud kooskõlas ... loengute teemad tulid nihkega, loengud tulid hiljem, rühmatöös pidime selle teemaga juba varem tegelema ... rühmatöö tegemine tundus väga keeruline ... me tegimegi seda viimased kaks nädalat ... jagasime ülesandeid (Ü.3.3)

Õppetöö korraldus. Intervjuudest ilmnes, et õppejõud lähenesid õppetöö korraldusele erinevalt: esimese ja teise juhtumi õppejõu taotluseks oli saavutada üliõpilaste järjepidev pühendumine aine õppimisele selle kaudu, et ainesse oli kavandatud rohkesti väiksema mahuga ülesandeid, mis olid ühtlaselt jaotatud tervele semestrile. Kolmanda juhtumi õppejõud planeeris ühe mahuka ülesande, mille esitamise tähtaeg oli määratud, kuid tegemise aja üle said üliõpilased ise otsustada. Isegi siis, kui tegevus oli sarnane (rohkesti ülesandeid ainekursuse jooksul), võisid õppejõudude eesmärgid olla erinevad. Näiteks esimese juhtumi õppejõul oli eesmärgiks saavutada üliõpilaste pidev õppimine ja haaratus aines.

Ma tahtsin, et nad tegutseksid óppimise aja jooksul, et nad pidevalt peaksid midagi tegema. (Õ.1)

Teise juhtumi õppejõu selgituste kohaselt oli tema soov, et võimalikult palju üliõpilasi läbiks õppeaine. Aine jooksul tehtavate ülesannete abil lõi ta üliõpilastele võimaluse koguda lisapunkte ning seeläbi saavutada suurema tõenäosusega positiivne hinne. Kolmanda juhtumi õppejõu intervjuust ilmnes tema arusaam, et üliõpilased on juba iseseisvad õppijad, ning seetõttu andis ta 
neile suurema vabaduse oma õppimise korraldamiseks. Samas kavandas õppejõud seminarid suurema rühmaprojekti vahekokkuvõtete tegemiseks.

Et ma jätsin neile võimaluse, et me käime üle nädala koos, võtame tehtu kokku, ma annan tagasisidet, ma annan uue ülesande. Siis see järgmine nädal, mis oleks ka pidanud seminar, et selle aja ma jätsin neile tunniplaanis, tegelemaks nü̈̈d kindlasti selle teemaga kas raamatukogus või ettevõttes või kuskil internetis. (Õ.3)

Kõikide juhtumite üliõpilaste intervjuude põhjal selgus, et üliõpilased tajusid ainekursuse jooksul tehtavaid ülesandeid õppimist toetavana, sest ülesanded võimaldasid neil pidevalt õpitavaga tegeleda. Kolmandas juhtumis väärtustati suurema ülesande jagamist etappideks ja võimalust seda teha pikema aja jooksul.

Kui pikaajaliselt õpid ... siis jäävad asjad paremini meelde, kui ópid ainult õhtul eksamiks, siis on kohe meelest läinud. (Ü.3.3)

Samas kirjeldasid mõned esimese juhtumi üliõpilased, et iganädalane ülesannete tegemine tähendas suurt töökoormust ning sellest tulenevalt õppisid mõned üliõpilased vahel pindmiselt.

Ma kirjutasin vahepeal pinnapealselt, siis kui olid kohutavad nädalad, kus oli igas aines väga pikad kirjalikud tööd teha. (Ü.1.6)

Õppimise juhendamine juhendite ja ajakava kaudu. Uurimuses osalenud õppejõud erinesid üliõpilaste õppimise juhendamise määra poolest. Esimese juhtumi õppejõud selgitas, kuidas ta andis väga konkreetseid juhiseid ülesannete tegemiseks ning väga kindla ajakava. Nii juhiseid kui ka ajakava selgitati üliõpilastele esimesel kohtumisel ning need olid üliõpilastele kirjalikult kättesaadavad. Õppejõud tuletas üliõpilastele lähenevaid tähtaegu ka meelde.

Ma liiga palju ja liiga tihti andsin neile teada, et noh ... kogu aeg olin nagu ema eest, et nüüd teete, et hakake nüüd seda tegema ja kogu aeg nagu suunasin seda protsessi ja neil oli kõik nagu ette ära kirjeldatud, et nende asi oli ainult tegutseda. (Õ.1)

Sama juhtumi üliõpilased kirjeldasid, kuidas nende õppimise suhtes väljendatud ootused, konkreetsed juhised ja kindlad tähtajad toetasid nende õppimist. Kolmanda juhtumi õppejõu intervjuust ilmnes, et ta esitas rühmaprojektiga seotud juhiseid suuliselt, selgitades, mida ja kuidas on vaja teha. Üliõpilased tõid välja, et nad ei saanud alati ülesandest või selle eesmärgist aru, ning seega suuliselt esitatud juhised ja tähtajad pigem ei toetanud nende õppimist. Samuti 
kirjeldas kolmanda juhtumi õppejõud, et ta arvestas üliõpilaste ajaga: kui ühel nädalal pole seminari, siis järelikult on üliõpilastel piisavalt aega järgmiseks nädalaks ette valmistada. Üliõpilaste kirjeldused peegeldasid, et vaba nädala funktsioon ei olnud neile piisavalt selge, kuna seda ootust üliõpilastele ei olnud väljendatud ning selleks vabaks nädalaks ei antud ka konkreetset ülesannet.

Pigem valmistusime seminariks kahel viimasel päeval. Puhkenädal, mis oli, seda ma ei kasutanud. See oleks võinud olemata olla ja selle asemel midagi praktilist asja tunnis teha. (Ü.3.4)

Kolme juhtumi võrdluse tulemusena võib järeldada, et õpetamist kavandades ei tarvitse õppejõud alati pöörata tähelepanu kooskõla loomisele. Üliõpilaste intervjuude põhjal ilmnes, et õppimist toetas, kui õppejõud oli mõelnud tegevuste eesmärkide, kooskõla ja järgnevuse peale ning üliõpilastel oli võimalik erinevate ülesannetega õppeprotsessi kestel tegeleda. Eri juhtumite üliõpilaste intervjuude analüüsi põhjal ilmnes, et üliõpilased ootavad juhendamist. Õppimise juhendamine ja õppimistegevuste eesmärkide väljendamine on õpikeskkonna element, mis võimaldab õppijal paremini enda õppimistegevusi mõtestada ja juhtida. Ebamääraselt või ainult suuliselt edastatud õppimise eesmärgid, juhised ja ootused ei toetanud üliõpilaste õppimist.

\section{Opetamine}

Õppemeetodid õppesisu omandamisel. Uurimusse kaasatud juhtumites kujundasid õppejõud õpikeskkonda mitmesuguste õppemeetodite kaudu. Teise ja kolmanda juhtumi õppejõud, kes otsustasid loengupidamise kasuks, tõid põhjendusena välja, et nende taotluseks on esitada materjal selgelt, arusaadavalt ja huvitavalt, et üliõpilased saaksid loengus kuuldu põhjal kursuse jooksul antavaid ülesandeid teha ning eksamil hästi vastata. Teise juhtumi õppejõu jaoks oli oluline, et loeng oleks võimalikult sisukas ning et üliõpilased oleksid loengus aktiivselt kaasatud.

Kuidas see loeng siis välja näeb? Ma jutustan ees, kasutan materjale, proovin hästi aktiivselt inimesi rääkima panna ... (Õ.2)

Teise juhtumi üliõpilased kirjeldasidki loengut huvitavana, loengupidajat entusiastlikuna, näiteid elulisena ja slaide asjakohasena ning nad tõid välja, et loeng toetas nende õppimist ja soodustas kaasamõtlemist.

Üritasin loengus kaasa mõelda. ... Kuna see oli huvitav aine ja óppejõud rääkis huvitavalt, ... üritasin kaasa mõelda ja enda jaoks meelde jätta. (Ü.2.9) 
Samas ilmnes üliõpilaste intervjuudest, et õppejõu esitatud küsimused tulid loengus neile ootamatult, nad ei olnud vastamiseks valmis ning tundsid end ebamugavalt.

Õppejõud küsis suvaliselt (üliópilaselt) ... et vastake ... no muidugi pidin mina vastama. Ma ei osanud midagi öelda, aga midagi ma ikkagi vastasin lõpuks ... närv tuleb sisse, kui ma ootamatult, ilma ettevalmistuseta pean vastama ... lisaks see, et nii palju inimesi oli ümber ... ma kardan, et vastan valesti. (Ü.2.7)

Kuigi kolmanda juhtumi õppejõud selgitas, kuidas ta loengus uut intot esitles, tõi näiteid ja jagas enda kogemusi, siis üliõpilased kirjeldasid loengut liiga lihtsustava ja igavana ning toodud näiteid õppejõukesksena. Üliõpilaste arvates ei toetanud selline loeng nende õppimist ning ning nad loobusid lõpuks loengusse tulemisest.

Vahepeal nagu kadus suund loengus ära ... kogu aeg loengu jutt jõudis ühte kohta tagas, jutt kordus lõpuks ja see oli põhjus, miks hästi palju ei käinud enam loengus (Ü.3.1)

Juhtumite võrdluse põhjal võib väita, et loengu kasulikkus õppimise toetajana ei sõltu mitte niivõrd loengust kui õppemeetodist üldiselt, kuivõrd konkreetse õppejõu loengu pidamise viisist ning ka sellest, kas ja kuidas üliõpilased on loenguks või seminariks valmistunud. Esimese juhtumi õppejõud selgitas, et ta otsustas loobuda loengutest ning asendada need iseseisva õppimise ja seminaridega. Selleks suunas ta üliõpilasi õppesisu omandamiseks õpikuga töötama. Vajalike algteadmiste omandamiseks kujundas õppejõud ülesandeid, mida tuli esitada enne vastava teema käsitlemist seminaris. Üliópilased kirjeldasid õpikuga töötamist kui õppimist toetavat tööviisi ning tõid välja iseseisvat õppimist suunava ülesande vajalikkuse.

Loengute asemel oli meil lugemispäevik ja minu arvates on see hea variant.

Siis saab paremini selgeks, kui oled eelnevalt kodus läbi töötanud selle teema.

(Ü.1.5)

Aruteluvõimalused seminaris või loengus. Kõikides uurimusse kaasatud juhtumites olid üheks tööviisiks seminarid, mis võimaldasid õpitava üle arutleda, teadmisi rakendada või tagasisidet saada. Kõik uurimuses osalenud õppejõud taotlesid, et üliõpilased töötaksid seminarides või loengutes kaasa ning arutleksid üksteise ja õppejõuga. Selle eesmärgi saavutamiseks kasutasid uurimuses osalenud õppejõud erinevaid tegevusi. Kuna sisukas arutelu saab võimalikuks, kui mõlemad pooled on selleks valmis (õppejõud loob võimaluse ja üliõpilane 
kasutab seda), võibki üliõpilaste intervjuude põhjal välja tuua, et üliõpilaste valmisolek aruteludes aktiivselt osaleda sõltus nende enda ettevalmistusest.

Esimese juhtumi õppejõud oli loonud süsteemi, mille puhul üliõpilased pidid seminariks tehtava eeltöö kohta postitama kokkuvõtteid ja küsimuste vastuseid õpikeskkonda Moodle, mis andis õppejõule teavet üliõpilaste koduse eeltöö kohta ning tagas, et üliõpilased olid seminariks valmistunud. Õppejõu kirjelduse põhjal oli seminarides oluline roll ülesannetel, mis toetasid arutelu.

Siis seminaris olid mul sellised igasugused mõtlemisülesanded, rühmatööd, mis me tegime, mingid juhtumid olid näiteks väga tihti ja mingisugused olukorrad ja situatsioonid ja siis me pidime teooria baasilt seda lahti mõtestama või lahendama neid olukordi. (Õ.1)

Üliõpilased teadvustasid, et enda ettevalmistus seminariks on vajalik ja tõid välja, et õppejõu loodud süsteem toetas neid eeltöö tegemisel, mis omakorda võimaldas neil seminarides sisukamat arutelu ning arusaamise kujundamist.

[Kui ei oleks olnud seminarieelseid kodutöid], siis ei oleks olnud nii palju arutelu, keegi ei oleks väga lugenud (kui ei oleks olnud kohustust ette valmistuda) ja siis ei oleks saanud kaasa rääkida ... (Ü.1.12)

Teise juhtumi õppejõud jättis loenguteks valmistumisel üliõpilastele vaba valiku, kas enne loengut õpikut lugeda või mitte, ning need teise juhtumi üliõpilased, kes ei olnud loenguks lugenud, tõdesid, et tehtud valik takistas nende aktiivset osalust.

Ma üldiselt hoian madalat profiili, eriti kui ma ei ole loenguks valmistunud ... ma pigem ei vasta. Loodan, et teised teevad seda. (Ü.2.13)

Kolmanda juhtumi õppejõu kirjelduste kohaselt oli ta kavandanud seminarid rühmaprojekti vaheetappide tutvustamiseks ja tagasiside saamiseks. Õppejõud selgitas, et ta ei nõudnud üliõpilastelt töö esitamist enne seminari, töö hetkeseisu tutvustasid üliõpilased seminaris suuliselt ning ka õppejõud andis soovitusi suuliselt.

Ma andsin valjusti tagasisidet, mida ma nägin ja missugused nende probleemid olid, pü̈̈dsin seal siis võibolla aidata ja teised ka kuulsid ja mitte ainult kuulanud, ma ütlesin, et kõik panevad nüüd tähele neid asju ja et oleks ruumis vaikus ja kõik peaksid lugu teineteisest ja iseendast. (Õ.3)

Sama juhtumi üliõpilaste selgituste kohaselt olid seminaris aktiivsed need üliõpilased, kes parajasti oma tööd tutvustasid, arutelusid ei tekkinud ning üliõpilaste jaoks tundus selline seminar kasutu. 
See oli hea, et tegime praktilist ülesannet. Aga seminarid olid täiesti mõttetud sellepärast, et kõik pidid andma ülevaate, mis nad olid teinud. See oleks kõik võinud olemata olla, sest ma ei kuulanud kordagi, mida teised grupid tegid. Seminaris tegelesime oma asjaga. (Ü.3.1)

Õhkkonna kujundamine. Esimese ja teise juhtumi õppejõudude intervjuud peegeldasid nende taotlust luua õppimist toetav õhkkond ning õhkkonda loovate tegevustena kirjeldati suhtlemist üliõpilastega, hoolivuse väljendamist, meeldetuletuste ja juhendavate meilide saatmist ning nendele vastamist. Teise juhtumi õppejõud tõi välja, et ta kasutas huumorit (vahel ka sarkastilisi nalju) ja julgustas üliõpilasi küsimusi esitama. Üliõpilased märkasid mõlema juhtumi puhul õppejõudude tegevusi õhkkonna loomisel ning leidsid, et loengutes ja seminarides valitsev õhkkond ning üldine suhtlusstiil toetas õppimist.

Keegi nagu ei pannud pahaks, kui sa valesti vastasid. Pigem oli see, et lihtsalt vastaksid ja avaldaksid oma arvamust ... ópiksid arvamust avaldama, see oli tähtsam ja siis ka teised muutuksid julgemaks ja rääkisid ja jõuti õige vastuseni. (Ü.2.10)

Ülesanded õppeprotsessis. Kõikide juhtumite õppejõud rakendasid õppeprotsessi kestel autentseid, s.o elulisi ülesandeid, mille eesmärk oli üliõpilaste õppimise toetamine (teadmiste rakendamine, oskuste arendamine, rühmatöö kogemuse omandamine). Üliõpilased tõstsid autentseid ülesandeid esile kui õppimist toetavat tegurit. Üliõpilaste kirjelduste põhjal võib välja tuua, et juhtumite erinevus seisnes ülesannete juhendite konkreetsuse ja täpsuse astmes. Näiteks esimese juhtumi õppejõud kirjeldas, kuidas ta püüdis ülesannete juhiseid anda võimalikult täpselt ja selgelt. Sama juhtumi üliõpilased kirjeldasid seda õppimist toetavana.

Iga töö puhul oli kohe alguses seletatud, mida ta selle tööga tahab, et mida me saavutaksime, kuidas me küsimustele vastaksime ja kindlasti (tuleb tuua) see põhjendus, seletus. See oli väga oluline. ... Kõik oli ilusti kirjas, mida ta ootab meilt. (Ü.1.3)

Õppejõud andis ülesande raames teatavaid valikuid (nt valida ise analüüsitav objekt), mida üliõpilased tajusid õppimist toetavana.

Intervjueerija: Ehk oleks tahtnud rohkem vabadust?

Üliõpilane: Teema sai ise valida. Ma arvan, et kui ta ei oleks konkreetselt mingeid piire seadnud, siis igaüks oleks midagi hoopis teistsugust teinud. (Ü.1.3)

Teise ja kolmanda juhtumi üliõpilased tõid välja, et ülesanded olid liiga ebamääraselt sõnastatud ning selline ülesande kirjeldus ei toetanud nende õppimist, 
Me ei olnud seda (ülesannet) mitte kunagi teinud, me ei teadnud, kuidas seda üldse tegema peab. ... Ma annaks rohkem infot selle kohta, mida sa tegema pead. (Ü.3.7)

Ülesannete juures erines õppejõudude kirjeldustes ka ülesannete kohustuslikkuse määr. Esimese juhtumi õppejõud toonitas, et enamik ülesandeid, mida üliõpilased õppeprotsessis tegema pidid, olid kohustuslikud. Teise ja kolmanda juhtumi õppejõud soovitasid üliõpilastel teooria kohta õpikust juurde lugeda, ent ei teinud seda kohustuslikuks. Teise juhtumi üliõpilaste intervjuudest selgus, et osa üliõpilasi järgis õppimisel õppejõu soovitusi, ent osa jaoks ei olnud soovitus iseseisvaks lugemiseks piisavalt tugev argument.

Ei olnud nagu sellist sundi või keegi oleks käskinud, et õpikut peab lugema. Eeldasingi, et see ongi võibolla neile rohkem, kes loengus aru ei saanud või ei julge küsida. ... Tegelikult on nii palju muid aineid ka ... ei tulegi see mõte, et loeks nü̈̈d õpikut või midagi ... (Ü.2.9)

Rühmatööd. Kõik õppejõud tõid välja, et nad kasutasid nii auditooriumis kui ka väljaspool tehtavate ülesannete puhul õppemeetodina rühmatööd. Ühegi õppejõu kirjeldustest ei ilmnenud, et nad oleks rühmatöö tegemist eraldi juhendanud. Erinevus juhtumites seisnes rühma suuruses: esimese juhtumi õppejõud lubas rühma suuruseks kolm-neli üliõpilast, teise ja kolmanda juhtumi õppejõud kuni kuus üliõpilast. Üliõpilaste rühmatöö kirjeldused viitasid, et suur rühm võis kujuneda õppimist takistavaks teguriks. Kuni nelja liikmega rühmade puhul selgitasid üliõpilased, et nad suutsid tööd rühmas tulemuslikult korraldada, kaasates kõiki rühma liikmeid ja vältides sotsiaalset looderdamist. Kui aga rühmas oli viis-kuus liiget, siis ilmnes kirjeldustest, et rühmatöö korraldamine kujunes probleemiks ning üliõpilasi häiris asjaolu, et mõned rühmaliikmed ei osalenud võrdväärselt teistega.

Meil oli kuueliikmeline rühm, mina ja veel kolm inimest tegime ära ... kaks inimest jäid nagu kõrvale. Ja see oli tegelikult sellepärast, et me neljakesi krahmasime kõik ülesanded endale. Et siis on teada, et saab tehtud [ülesanne]. (Ü.2.11)

Tagasiside õppeprotsessis. Intervjuudes kajastus õppejõudude arusaam tagasiside andmise vajalikkusest õppeprotsessis. Kõik õppejõud rõhutasid, et tagasiside andmise oluline eesmärk on üliõpilaste õppimise toetamine. Õppejõudude praktiline tegevus selle taotluse elluviimisel osutus erinevaks ning sellest tulenevalt kirjeldasid eri juhtumite üliõpilased tagasiside tähendust oma õppimisele erinevalt. Õppejõudude tegevus erines selle poolest, kuivõrd nad lõid üliõpilastele võimalusi tagasiside kasutamiseks edasises õppeprotsessis. 
Esimese juhtumi õppejõud andis üliõpilaste viimistlusjärgus töödele individuaalset kirjalikku tagasisidet, ootas muutuste tegemist tagasiside põhjal ning vajaduse korral nõudis parandatud tööde uuesti esitamist.

Sellel aastal ma andsin tagasisidet ka niimoodi neile, et selle töö [nimetab ülesande] osas ma veel panin töö (esimene versioon) lõppu neile (hindamiskriteeriumide) tabeli. Viis kriteeriumit on mul seal ja mitu punkti nad siis said igast kriteeriumist ja kirjutasin kommentaari ka. Neil on muidugi tööjuhendi taga suur tabel, seal oli näha, mida näiteks kaks punkti tähendab ... ja mõnel juhul ma kirjutasin ka juurde, et see oli nagu kokkuvõte selline ... Ma tahtsin neile näidata, kus nad on oma asjaga praegu. (Õ.1)

Üliõpilased tajusid sellist tagasisidet õppimist toetavana, sest see võimaldas mõista, millises suunas nad peavad oma tööd edasi arendama.

Õppejõud andis koheselt meile tagasisidet ja siis me saime teada, mis seal valesti on ja mida on vaja parandada ... meil oli kolm nädalat aega oma tööd parandada (Ü.1.9)

Teise juhtumi puhul andis õppejõud hindamiseks esitatud töödele suulist tagasisidet, põhjendades antud punkte, tuues välja töödes leidunud probleeme ja andes soovitusi ning lootis, et üliõpilased kasutavad saadud tagasisidet järgmiste ülesannete täitmisel.

Ma peas panen oluliselt rohkem tähtsust tagasisidele, mida ma püüan anda nii palju kui võimalik on 200 inimesega. Ma ei saa personaalselt kellelegi öelda, ma mõnele olen öelnud et või noh kasvõi klassi ees noh kiitnud, sarkastiliselt kiitnud. (Õ.2)

Hindamiseks esitatud tööde puhul ei olnud üliõpilastel õppejõu kommentaaride põhjal enam võimalik oma töid muuta. Üliõpilaste intervjuud viitasid, et tagasisidet oli küll tore saada, ent nende õppimist selles aines see enam ei mõjutanud. Kolmandas juhtumis oli suur ülesanne jagatud osadeks ning õppejõud andis seminaris esitletud osadele suulist tagasisidet, eeldades, et üliõpilased arvestavad seda oma töö tegemisel. Üliõpilased kirjeldasid tagasisidet pealiskaudsena, kuna nad ei mõistnud, et õppejõu kommentaarid oleks neil aidanud tööd arendada. Lisaks segas tagasiside vastuvõtmist ka seminari korraldus.

Seal oli kuus rühma, poolteist tundi aega, lugesime igaüks ette, mis me oleme leidnud, õppejõud kuulas, natuke vaatas ning läksime edasi. ... Ühel korral ta ütles, et väga hea, võiks natuke nii teha ja küsis, et mis sa arvad, kas võiks nii. Aga mina ju ei tea. Sellepärast ma tulingi tundi, et teie käest küsida. Ma istusin seal [seminaris] oma aja ära, pü̈̈dsin tähele panna, aga nagu ühest korrvast sisse, nii läks ka teisest välja. Midagi olulist ei olnud sealt saada. (Ü.3.5) 
Juhtumite võrdlusena saab välja tuua, et õpikeskkonna loomisel kasutasid õppejõud õpetamisel mitmesuguseid õpetamistegevusi. Üliõpilaste intervjuude analüüsi põhjal võib osutada, et õppimist toetas, kui õppija sai juba teadmiste loomise etapis aktiivselt osaleda ning oli osalemiseks ise piisavalt ette valmistanud. Võrreldes kolme juhtumi üliõpilaste ülesannetega seotud kirjeldusi, ilmnes, et üliõpilaste õppimist toetasid selgelt sõnastatud ja autentsed ülesanded. Kuigi rühmatöö rakendamine peegeldab õppimiskeskset õpetamisviisi, ilmnes eri juhtumite üliõpilaste intervjuude analüüsist, et kui protsessi ei ole juhendatud, siis rühmatöö ei tarvitse alati õppimist toetada. Samuti ilmnes juhtumite võrdlusest, et kuigi kõigi juhtumite õppejõud pidasid tagasisidet oluliseks ning $\mathrm{ka}$ andsid seda, siis tagasiside tähtsus õppimisel sõltus võimalusest seda töö arendamisel kasutada.

\section{Hindamine}

Hindamiskriteeriumid. Õppejõudude intervjuude põhjal olid hindamiskriteeriumid sõnastatud kahe juhtumi puhul. Esimese juhtumi õppejõu taotlus hindamiskriteeriumide sõnastamisel oli saavutada olukord, et üliõpilastel oleks selge, mida nendelt konkreetse ülesande puhul oodatakse. Õppejõud kirjeldas, et hindamiskriteeriumid olid üldjuhul lisatud konkreetse ülesande juhendi juurde. Esimese juhtumi üliõpilased kirjeldasid, kuidas hindamiskriteeriumid olid nende õppimist toetavaks teguriks, sest need olid kirjalikult ja selgelt väljendatud.

Õppejõul olid tohutud kriteeriumid, mille järgi ta hindab, punkte paneb. Me võtsimegi need kriteeriumid ette ja vaatasime, millega 20 punkti saab ... peab vaeva nägema (Ü.1.3)

Teise juhtumi õppejõud kirjeldas, et tal olid kriteeriumid enda jaoks olemas, ning rühmatöid hinnates ta andis kriteeriumide alusel kirjalikult punkte. Samas tunnistas õppejõud intervjuus, et kuigi kriteeriumid olid sõnastatud, mõjutas tööde hindamisel teda siiski ka üldmulje, mis üliõpilaste õppimisest oli semestri jooksul kujunenud.

Aga jah, iga töö ma võtsin siis viieks lahti tegelikult ja igale tööle sai antud viis erinevat hinnet, et noh ... nad tulid ikkagi subjektiivselt tegelikult kõhutunde alusel. (Õ.2)

Sama juhtumi üliõpilased tajusid, et õppejõud oli neile liiga kergekäeliselt punkte andnud. Kolmanda juhtumi õppejõud kasutas kirjelduse kohaselt võrdlushindamist, järjestades üliõpilaste töid sisukuse alusel ja enda ideaali 
põhjal ning võttes punkte maha, kui üliõpilase töös ilmnes puudujääke. Selle juhtumi üliõpilased kirjeldasid segadust, mida teadmatus hindamiskriteeriumide suhtes neis tekitas.

Ma olin hullult pettunud (nimetab töö) punktides, ilmselt vormistus võttis jõhkralt maha punkte (Ü.3.5)

Hinde kujunemine. Õppejõudude kirjelduse kohaselt kujunes hinne hindamisülesannete või eksami koondpunktide tulemusena. Põhimõtteliselt rakendasid õppejõud pidevhindamise põhimõtteid, kuid rõhuasetused olid erinevad ning ainekursuse jooksul kogutud punktide ja lõppeksami tähendus oli õppejõudude jaoks samuti erinev. Esimese juhtumi puhul oli eelnevate ülesannete tegemine eelduseks eksamile saamiseks (kõik ülesanded ei olnud hindelised) ning kokkuvõtva eksami eesmärk oli õpiväljundite omandamise kontrollimine. Teise juhtumi puhul andsid ainekursuse jooksul tehtud tööde eest kogutud punktid üliõpilastele võimaluse saada parem lõpphinne. Pidevhindamise tähendusest õppimisele rääkisid ainult teise juhtumi üliõpilased. Osa õppijaid tôi välja, et pidev punktide kogumine motiveeris neid kogu aine jooksul kaasa töötama, ent mõned sama juhtumi üliõpilased kirjeldasid, kuidas nad eksamiks enam ei valmistunud, sest vajalikud punktid olid juba koos.

Mul oli enne eksamit väga hea seis, mul oli 50 võimalikust punktist 44 olemas. Mul oli võimalus A-ks ja see andis mulle nii hea enesekindluse, et kui ma läksin eksamit tegema, siis ma ei ôppinud eksamiks absoluutselt. ... Eksami 50 võimalikust punktist sain 22. (Ü.2.11)

Seega kirjeldasid sama juhtumi üliõpilased pidevhindamist nii õppimist toetava kui ka takistava tegurina.

Hindamisel on oluline roll hindamiskriteeriumidel ning nende tähendus õppimist toetava tegurina ilmnes ka selles uuringus. Hinde kujundamine erinevate õppeaine jooksul tehtavate tööde koondpunktide tulemusena võib toetada mõne üliõpilase õpimotivatsiooni, kuid mõne õppija puhul võib seda õppeprotsessi lõpuks hoopis vähendada.

\section{Kokkuvõttev arutelu}

Uurimuse eesmärk on mõista, kuidas on omavahel seotud õppejõudude kirjeldatud õpikeskkonna elemendid, mida analüüsiti õpetamisviiside kaudu, ning üliõpilaste kirjeldatud õppimist toetavad ja takistavad tegurid. Nimetatud seoste võrdlus kolmes juhtumis võimaldab mõista, miks õppimiskesksele õpetamisviisile omased õpetamis- ja hindamistegevused alati ei toeta õppimist. 
Veel võimaldavad saadud tulemused selgitada, kuidas õpetamisviiside põimumine avaldub üliõpilaste õppimist toetavate ja takistavate tegurite kirjeldustes.

Siinsest uurimusest selgus, millistel tingimustel õppimiskesksele õpetamisviisile omane õpetamistegevus toetab või ei toeta üliõpilaste õppimist. Kuigi õppejõud rakendavad õppimiskesksele õpetamisviisile omaseid elemente õppeainete õpetamisel, võib teatud asjaolude mittearvestamine vähendada õppimiskesksele õpetamisviisile omase elemendi rakendamisest loodetud kasu õppimisele. Näiteks aruteluvõimaluste pakkumist peetakse üldjuhul õppimiskesksele õpetamisviisile ja konstruktivistlikule õpikeskkonnale omaseks elemendiks (Postareff \& Lindblom-Ylänne, 2008; Tynjälä, 1999) ning see peaks toetama üliõpilaste õppimist (Baeten et al., 2010). Praeguse uuringu põhjal saab täpsustada, et aruteluvõimaluste pakkumine on oluline, kuid arutelu sisukus sõltub nii sellest, millised võimalused on õppejõud üliõpilastele loonud arutelu eeltööks (materjalid, ülesanded), kui ka sellest, kuivõrd üliõpilased ise neid võimalusi kasutavad. Lisaks osutus määravaks, milliseid ülesandeid on õppejõud arutelude algatamiseks loonud.

Samuti on õppimiskesksele õpetamisviisile omane autentsete ülesannete loomine. Siinne uurimus toob välja, et üliõpilaste kirjelduste põhjal võib õppimiskesksete ülesannete vähene juhendamine osutuda õppimist takistavaks teguriks. Kuigi kõigi juhtumite üliõpilased kinnitasid, et eluline ülesanne üldiselt toetas nende õppimist, ei toetanud autentne ülesanne õppimist ülesannete juhendamise erinevuse tõttu iga juhtumi puhul. Siinne uurimus näitas, et õppimist toetab autentne ülesanne koos täpsete ja selgete juhenditega. Ka varasemates uurimustes (Baeten, Dochy, Struyven, Parmentier, \& Vanderbruggen, 2016) on leitud, et õppejõu juhendamine ja toetus on sama olulised kui õppimiskesksed õpetamis- või hindamistegevused.

Õppimiskeskses õpetamisviisis tähtsustakse tagasiside rolli, kuid on leitud, et üliõpilased ei kasuta saadud tagasisidet õppimisel alati tulemuslikult (Winstone, Nash, Rowantree, \& Parker, 2016). Kuigi siinses uurimuses kirjeldasid kõik õppejõud tagasiside andmist (tööde suuline kommenteerimine, kirjalik tagasiside hindamiskriteeriumide põhjal, tööde arendamine tagasisidest lähtuvalt), toetas üliõpilaste hinnangul nende õppimist selline tagasiside, mida nad said õppeprotsessis (s.o ülesande arendamisel) kasutada. Uurimus kinnitas, et õppimise toetamiseks on oluline silmas pidada tagasiside andmise kohta õppeprotsessis ja sellega kaasnevat ülesannet. Sarnase tulemuseni on jõudnud Esterhazy jt (2019), leides, et tagasiside on õppimise seisukohalt tulemuslik siis, kui see on õppijatele mõistetav ning kui õppejõud on loonud selle rakendamiseks võimalusi.

Varasemates kõrghariduses tehtud uurimustes (Baeten et al., 2010; Hailikari et al., 2018), milles on käsitletud üliõpilaste õppimist toetavaid ja takistavaid 
tegureid, on ühe õppimist takistava tegurina kirjeldatud suurt töökoormust. Siinseski uuringus viitasid üliõpilaste kirjeldused, et kuigi pidevad ülesanded toetasid üliõpilaste õppimist, võis ülesannete hulk kaasa tuua pindmist õppimist. Seetõttu on õppimiskeskse õpetamisviisi puhul risk, et iseseisvate ülesannete rohkus ei toeta üliõpilaste sügavat õppimist.

Eelnevat kokku võttes võib väita, et õppimiskesksele õpetamisviisile omased õpetamis- ja hindamistegevused (nt aruteluvõimalus loengus, autentsed ülesanded, tagasiside) toetavad õppimist, kui üliõpilased tajuvad, et õppimistegevused on piisavalt juhendatud. Ilmnes, et üliõpilased vajasid põhjalikumat juhendamist õppimiskesksele õpetamisviisile omaste ülesannete puhul just nendes õpikeskkondades, kus põimusid õppimis- ja sisukeskne õpetamisviis ning võib oletada, et seda suuresti seetõttu, et õpetamisviiside põimumise korral ei ole üliõpilased alati õppimiskeskseks õpetamisviisiks valmis.

Siinse uurimuse tulemused kinnitasid, et konkreetse õppeaine õpetamise kirjeldustes esineb õppimis- ja sisukeskse õpetamisviisi põimumist õpetamise kavatsuste ja õpetamistegevuste vahel (Postareff et al., 2008; Stes \& Van Petegem, 2014). Meie uurimus lisab, et õpetamisviiside põimumine ilmneb ka konkreetse õppeaine õpikeskkonna õpetamis- ja hindamistegevuste kirjeldustes, viidates, et õppejõu õpetamistegevus ei tarvitse alati toimuda ühe õpetamisviisi kohaselt. Kõrvutades õppejõudude õpetamisviisi kirjeldusi ning üliõpilaste kirjeldatud õppimist toetavaid ja takistavad tegureid, võib järeldada, et üliõpilased tajuvad õpetamisviiside põimumist segadust tekitavana. Siinsest uuringust ilmnes, kuidas õppimiskeskne õpetamine ja sisukeskne hindamine tekitasid üliõpilastes segadust ja pettumust, sest õppeprotsessis rakendatud ülesanded suunasid õppijaid teatud viisil kokkuvõtvaks hindamiseks ehk eksamiks õppima. Uurimuse tulemused kinnitavad õpetamise ja hindamise vahelise kooskõla olulisust (Biggs \& Tang, 2008) ning samas kinnitavad ka seda, et õppeaine tasandil võivad põimuda õppimise suhtes mõneti vastandlike ootustega õpetamisviisid. Teadvustades õpetamisviiside põimumist, on vaja selgitada õppijatele erinevate õpetamis- ja hindamistegevuste kasutamise eesmärki ja otstarvet, tõstes seeläbi õppijate teadlikkust ning juhendades õppimist.

Õppimise juhendamine ei pruugi olla kõrghariduse kontekstis nii ilmne ja oluline, kuna arvatakse, et kõrgkoolis õppija on iseseisev ja ennastjuhtiv täiskasvanu (Postareff \& Lindblom-Ylänne, 2008; Wilcox, 1996). Samas on piir õppimise juhendamise ja liigse kontrolli vahel õhuke. Kõik see loob pinnase dilemmaks: kuidas luua struktuur, mis toetab õppimist, võtmata üliõpilaselt kui täiskasvanud õppijalt tema autonoomsust (Wilcox, 1996). Siinne uurimus võimaldab väita, et õppimise juhendamine, st ootuste, ülesannete ja hindamiskriteeriumide selgitamine ja kirjeldamine, ei kahandanud õppija iseseisvust, vaid võimaldas oma õppimist juhtida. Näiteks pigem tekitas juhiste 
ebamäärasus õppijates peataolekut ja vähendas haaratust õppimisel. Kuigi ka siinses uurimuses väärtustasid üliõpilased valikute tegemise võimalust, mida peetakse oluliseks õppija autonoomsust toetavaks teguriks (Jang, Reeve, \& Deci, 2010; Wilcox, 1996), jätsid õppejõudude soovitused teatud õppimistegevusi teha mõned uurimuses osalenud üliõpilased siiski arvestamata. See kinnitab veel kord, kuivorrd keeruline on õppimise juhendamise ja autonoomsuse vahel tasakaalu leida.

Siinne uuring tehti bakalaureuseõppe kontekstis ning uuringu peamiseks piiranguks on, et tulemusi ei pruugi saada üle kanda teiste valdkondade (nt reaalteadused) ja järgmiste õppeastmete (nt magistriõpe) õppeainete õpikeskkondadele. Seetõttu võiks sarnast uurimust korrata ka teistes valdkondades, et mõista õppimist mõjutavaid tegureid erilaadsetes õppeainete õpikeskkondades.

\section{Kasutatud kirjandus}

Almeida, P. A., Teixeira-Dias, J. J., Martinho, M., \& Balasooriya, C. D. (2011). The interplay between students perceptions of context and approaches to learning. Research Papers in Education, 26(2), 149-169. https://doi.org/10.1080/02671522.2011.561975

Baeten, M., Dochy, F., Struyven, K., Parmentier, E., \& Vanderbruggen, A. (2016). Student-centred learning environments: an investigation into student teachers' instructional preferences and approaches to learning. Learning Environments Research, 19(1), 43-62. https://doi.org/10.1007/s10984-015-9190-5

Baeten, M., Kyndt, E., Struyven, K., \& Dochy, F. (2010). Using student-centred learning environments to etimulate deep approaches to learning: Factors encouraging or discouraging their effectiveness. Educational Research Review, 5(3), 243-260. https://doi.org/10.1016/j.edurev.2010.06.001

Barnett, R., \& Guzmán-Valenzuela, C. (2017). Sighting horizons of teaching in higher education. Higher Education, 73, 113-126.

https://doi.org/10.1080/0729436042000235382

Biggs, J., \& Tang, C. (2008). Õppimist väärtustav õpetamine ülikoolis. Tartu: Tartu Ülikooli Kirjastus.

Brinkmann, S. (2014). Unstructured and semi-structured interviewing. Kogumikus P. Leavy (toim) The Oxford Handbook of Qualitative Research, (lk 277-299). Oxford: Oxford University Press.

Entwisle, N. (2007). Research into student learning and university teaching. British Journal of Educational Psychology Monograph Series, II(4): 1-18.

Entwistle, N., McCune, V., \& Hounsell, J. (2002). Approaches to Studying and Perceptions of University Teaching-Learning Environments: Concepts, Measures and Preliminary Finding. Occasional Report 1. ETLProject, Universities of Edinburgh, Coventry and Durham. Vaadatud 01.05.2019, https://www.researchgate.net/publication/313443807_Approaches_to_Studying_and_Perceptions_of_University_ TeachingLearning_EnvironmentsConcepts_Measures_and_Preliminary_Findings 
Esterhazy, R., Nerland, M., \& Damşa, R. (2019). Designing for productive feedback: An analysis of two undergraduate courses in biology and engineering. Teaching in Higher education, https://doi.org/10.1080/13562517.2019.1686699

Gijbels, D., Segers, M., \& Struyf, E. (2008). Constructivist learning environments and the (im)possibility to change students' perceptions of assessment demands and approaches to learning. Instructional Science, 36, 431-443.

https://doi.org/10.1007/s11251-008-9064-7

Hailikari, T., \& Parpala, A. (2014). What impedes or enhances my studying? The interrelation between approaches to learning, factors influencing study progress and earned credits. Teaching in Higher Education, 19(7), 812-824. https://doi.org/10.1080/13562517.2014.934348

Hailikari, T., Tuononen, T., \& Parpala, A. (2018). Students' experiences of the factors affecting their study progress: differences in study profiles. Journal of Further and Higher Education, 42(1), 1-12. https://doi.org/10.1080/0309877X.2016.1188898

Jang, H., Reeve, J., \& Deci, E. L. (2010). Engaging students in learning activities: It Is Not Autonomy Support or Structure but Autonomy Support and Structure. Journal of Educational Psychology, 102(3), 588-600. https://doi.org/10.1037/a0019682

Kember, D., \& Kwan, K. (2000). Lecturer's approaches to teaching and their relationship to conceptions of good teaching. Instructional Science, 28(5): 469-490. https://doi.org/10.1023/A:1026569608656

Kyndt, E., Dochy, F., Struyven, K., \& Cascallar, E. (2011). The perception of workload and task complexity and its influence on students' approaches to learning: a study in higher education. European Journal of Psychology of Education, 26(3): 393-415. https://doi.org/10.1007/s10212-010-0053-2

Mumm, K., Karm, M., \& Remmik, M. (2016). Assessment for learning: Why assessment does not always support student teachers' learning. Journal of Further and Higher Education, 40(6): 780-803.

https://doi.org/10.1080/0309877X.2015.1062847

Parpala, A., Lindblom-Ylänne, S., Komulainen, E., Litmanen, T., \& Hirsto, L. (2010). Students' approaches to learning and their experiences of the teaching-learning environment in different disciplines. British Journal of Educational Psychology, 80(2), 269-282. https://doi.org/10.1348/000709909X476946

Parpala, A., Lindblom-Ylänne, A., \& Rytkönen, H. 2011. Students' conceptions of good teaching in three different disciplines. Assessment and Evaluation in Higher Education, 36, 549-563. https://doi.org/10.1080/02602930903541023

Postareff, L., \& Lindblom-Ylänne, S. (2008). Variation in teachers' descriptions of teaching: Broadening the understanding of teaching in higher education. Learning and Instruction, 18(2), 109-120.

https://doi.org/10.1016/j.learninstruc.2007.01.008

Postareff, L., Katajavouri, N., Lindblom-Ylänne, S., \& Trigwell, K. (2008). Consonance and dissonance in descriptions of teaching of university teachers. Studies in Higher Education, 33(1), 49-61. https://doi.org/10.1080/03075070701794809

Prosser, M, Ramsden, P., Trigwell, K., \& Martin, E. (2003). Dissonance in experience of teaching and its relation to the quality of student learning. Studies in Higher Education, 28(1), 37-48. https://doi.org/10.1080/03075070309299 
Prosser, M., \& Trigwell, K. (2014). Qualitative variation in approaches to university teaching and learning in large first-year classes. Higher Education, 67(6), 783-795. https://doi.org/10.1111/j.2044-8279.1997.tb01224.x

Ruohoniemi, M., \& Lindblom-Ylänne, S. (2009). Students' experiences concerning course workload and factors enhancing and impeding their learning - a useful resource for quality enhancement in teaching and curriculum planning. International Journal for Academic Development, 14(1), 69-81. https://doi.org/10.1080/13601440802659494

Samuelowicz, K., \& Bain, J.D. (1992). Conceptions of Teaching Held by Academic Teachers. Higher Education, 24(1), 93-111. https://doi.org/10.1007/BF00138620

Schreier, M. (2012). Qualitative Content Analysis in Practice. SAGE.

Segers, M., Martens, R., \& Van den Bossche, P. (2008). Understanding how a casebased assessment instrument influences student teachers' learning approaches. Teaching and Teacher Education, 24(7), 1751-1764. https://doi.org/10.1016/j.tate.2008.02.022

Stes, A., \& Van Petegem, P. (2014). Profiling approaches to teaching in higher education: a cluster-analytic study. Studies in Higher Education, 39(4), 644-659. https://doi.org/10.1080/03075079.2012.729032

Struyven, K., Dochy, F., Janssens, S., \& Gielen, S. (2006). On the dynamics of students' approaches to learning: The effects of the teaching/learning environment. Learning and Instruction, 16(4), 279-294. https://doi.org/10.1080/02602930500099102

Thomas, G. (2016). How to do your case study? ( $2^{\text {nd }}$ ed). Sage.

Trigwell, K., Prosser, M., \& Taylor, P. (1994). Qualitative differences in approaches to teaching first year university science. Higher Education, 27(1): 75-84. https://doi.org/10.1007/BF01383761

Tynjälä, P. (1999). Towards expert knowledge? A comparison between a constructivist and a traditional learning environment in the university. International Journal of Educational Research, 31(5), 357-442. https://doi.org/10.1016/S0883-0355(99)00012-9

Uiboleht, K., Karm, M., \& Postareff, L. (2018). The interplay between teachers' approaches to teaching, students' approaches to learning and learning outcomes: a qualitative multi-case study. Learning Environments Research, 21(3), 321-347. https://doi.org/10.1007/s10984-018-9257-1

Van Driel, J. H., Verloop, N., Van Werven, H. I., \& Dekkers, H. (1997). Teachers' craft knowledge and curriculum innovation in higher engineering education. Higher Education, 34(1): 105-122. https://doi.org/10.1023/A:1003063317210

Wilcox, S. (1996). Fostering self-directed learning in the university setting. Studies in Higher Education, 21(2), 165-176. https://doi.org/10.1080/03075079612331381338

Winstone, N. E., Nash, R. A., Rowntree, J., \& Parker, M. (2016). 'It'd be useful, but i wouldn't use it': Barriers to university students' feedback seeking and recipience. Studies in Higher Education, 42(11), 1-16.

https://doi.org/10.1080/03075079.2015.1130032 


\title{
Relations between teachers' approaches to teaching and students' perceptions of enhancing and hindering elements of the teaching-learning environment
}

\author{
Kaire Uiboleht ${ }^{\text {al }}$, Mari Karm ${ }^{\text {ab }}$ \\ ${ }^{a}$ The Centre for Professional Development, University of Tartu \\ ${ }^{b}$ Institute of Education, University of Tartu
}

\section{Summary}

\section{Theoretical framework}

In the context of higher education, the university teacher has a main role and responsibility in developing the teaching-learning environment (TLE) of the course (Barnett \& Guzmán-Valenzuela, 2017). Therefore, it is possible to describe the TLE of the course employing approaches to teaching theory, which focuses on teachers' intentions and strategies and captures several aspects of the TLE (Postareff \& Lindblom-Ylänne, 2008). Previous studies have described two broad categories of approaches to teaching: content-focused and learning-focused approaches to teaching (Kember \& Kwan, 2000; Postareff \& Lindblom-Ylänne, 2008). The intention of teaching for content-focused approach to teaching is to transmit the course content. Teaching strategies are often described as delivering the course content and teachers' examples are employed. The role of the students is described as passive, i.e. main learning activity is to listen and absorb the information. The intention of assessment is described as ensuring the learning of the material and supporting external motivation. Therefore, more traditional assessment methods are adopted. The variety of both teaching and assessment practices is low.

The intention of teaching for learning-focused approaches to teaching is described more as encouraging the development of deep understanding, conceptual change and development of generic skills. Therefore, the role of students is often described as active creators and constructors of knowledge. Teaching strategies are described as offering possibilities for students to constantly engage and interact. The intention of assessment practices is to value and support the development of deep understanding and, therefore, more

The Centre for Professional Development, Human Resources Office, University of Tartu, Lossi 36, Tartu, 51003 Estonia; kaire.uiboleht@ut.ee 
authentic assessment tasks are often employed. For this teaching approach the variety of teaching and assessment methods and tasks is high. Research in the field of approaches to teaching have also indicated that teachers may combine elements from both approaches (Postareff et al., 2008; Stes \& Van Petegem, 2014).

Researchers on teaching and learning in higher education have indicated that the TLE of the course (i.e. teachers approach to teaching) does not directly influence students' learning, but more important is how students perceive the TLE (Baeten et al., 2010, Entwistle, 2007). In general, research has described elements that enhance and hinder students' learning or encourage deep or surface approaches to learning (Baeten et al., 2010; Esterhazy et al., 2019; Hailikari \& Parpala 2014; Kyndt et al., 2011; Parpala et al., 2010; Parpala et al., 2011; Ruohoniemi \& Lindblom-Ylänne 2009; Sambell et al., 1997; Struyven et al., 2006).

Students perceive the TLE as enhancing their learning or they probably adopt deep approaches to learning when they perceive elements of the TLE, such as: 1) alignment between learning outcomes, teaching and assessment; 2) pre-set timetables or study plans; 3 ) teaching is interesting and relevant; 4) there are possibilities to constantly engage with and apply learning material; 5) interaction with peers or the teacher; 6) enthusiasm of the teacher; support and explanations; 6) feedback and possibility to develop the assignment further; 7) authentic tasks. The elements of the TLE are perceived by students as hindering or students describe adopting surface approaches to learning when: 1) there are few classroom meetings, feedback and interaction; 2) the level of guidance is low (e.g. the assignments are ill-structured); 3) assessment is mainly summative. Too big or too little workload, or assignments that are too challenging or too easy for students (e.g. assignments/tasks) also hinder learning.

Previous research (e.g. Hailikari et al., 2018; Postareff and Lindblom-Ylänne, 2008), that describes the students' perceptions of the elements of the TLE that enhance or hinder their learning tends to be rather general or is focused on the curriculum level. Moreover, there are few researches that would explore the relations between students' perceptions of the TLE and teachers' approaches to teaching at the course level. Understanding these relations is crucial from the perspective of course development. Therefore, the current research is focused on exploring how the elements of teachers' approaches to teaching and the elements of the TLE that are perceived as enhancing or hindering their learning are related. 


\section{Research methods}

This qualitative study employs a multi-case research design (Thomas, 2016) to capture how the teachers' approaches to teaching are related to the elements of the TLE that are perceived by students as hindering or enhancing. Firstly, in the process of selecting the cases i.e. courses for the study, it was important that their field, level, content and learning outcomes were similar as suggested by Baeten et al. (2010). Therefore, one case in this study represents one compulsory undergraduate course in the field of social sciences, which had the same content and similar learning outcomes. Secondly, it was important that the TLE of the courses would differ from the perspective of teaching and assessment practices. Three teachers responsible for teaching and assessment of the selected courses agreed to participate in the study. Data was collected employing individual semi-structured interviews from teachers and students (teachers $\mathrm{N}=3$, students $\mathrm{N}=33$ ). Qualitative inductive content analysis was used to analyse the data of both groups of participants.

\section{Results}

The study found that two teachers out of three combined content- and learning-focused approaches to teaching, thus reaffirming the results of earlier research (Postareff et al., 2008; Stes \& Van Petegem, 2014).

Combining approaches to teaching does not necessarily mean that students perceive it as hindering their learning when they perceive how and what they must study. Students described an inconsistency between the learning process and the summative assessment method as a factor hindering their learning as the tasks implemented during the learning process guided students towards a certain way of learning. When a different type of a task was used as a summative assessment method, it resulted in the students not learning in the way a teacher assumed, nor in the way the examination paper was designed and by the end of the course students became disappointed. Consequently, it is very important for the teacher to describe his or her expectations more precisely when using different types of assessment methods and tasks.

Students perceived lectures and seminars interesting, when it was possible to solve problems and discuss the subject matter, in groups with peers, and thus, supporting their learning. Meaningful learning in seminars emerged in students' descriptions when they were well-prepared for a seminar. The opposite situation diminished student participation in lectures and seminars.

Students' descriptions showed that a continuous flow of assignments supports their learning when the amount of assignment is adequate and in case the assignments are compulsory (Ruohoniemi \& Lindblom-Ylänne, 2009; 
Varunki et al., 2017). This study enabled to understand the interaction between compulsory and optional learning activities. Results showed that when a teacher suggested a book to be read before lectures, most of the students did not comply. When a teacher wants bachelor's level students to carry out certain learning activities, the authors recommend making the assignments compulsory as students may have problems organising their learning and managing time (Hailikari et al., 2018).

As to the assignments implemented within a course it became evident that they supported students' learning if they were authentic, however, when a task was ill-formulated it did not support the learning process (Hailikari \& Parpala, 2014). Furthermore, from the point of view of learning it is important that students have the possibility for feedback to improve their tasks, meaning that feedback will be productive from the perspective of learning as suggested by Esterhazy et al. (2019).

To sum up, combining approaches to teaching is not necessarily perceived by the students as hindering their learning. Students' learning is above all hindered by ambiguous expectations and instructions.

Keywords: teaching-learning environment, approaches to teaching, students' perceptions of enhancing elements of the TLE, students' perceptions of hindering elements of the TLE 